\title{
Acipenser stellatus as a new host record for Lernaea cyprinacea linnaeus, 1758 (crustacea; copepoda), a parasites of freshwater fishes in Iran
}

\begin{abstract}
Acipenser stellatus is the most euryhaline sturgeon in the Caspian Sea which is reputed to have the tastiest flesh and also the best caviar in Iran. The main objective of the current study was to investigate the gill parasites of $A$. stellatus in "Rajaee Aquaculture Centre" in northeast of Caspian Sea Basin, Mazandaran Province. A total of 22 individuals were selected accidentally and examined for the parasites during the spring of 2017. Six adult female of Lernaea cyprinacea L. 1758, an ectoparasitic copepod species was detected on the gill filaments and archs. Five (22.7\%) out of 22 specimens of the examined fish were infected with adult anchor worms containing egg sacs and A.stellatus is presented as a new host for L.cyprinacea in the present report. The presence of this parasite on sturgeon fishes has not previously been reported in all over the world. Also this is the first report of occurrence of adult female of L.cyprinacea on the fish gills.
\end{abstract}

Keywords: Acipenser stellatus, adult Lernaea cyprinacea, gills, caspian sea
Volume 7 Issue 3 - 2018

\author{
Abbas Bozorgnia,' Neda Sharifi, ${ }^{2}$ Mohammad \\ Reza Youssefi, ${ }^{3}$ Maryam Barzegar ${ }^{4}$ \\ 'Assistant Professor, Faculty of Natural Resources Sciences, \\ QaemShahrBranch, Islamic Azad University, Iran \\ ${ }^{2}$ Department of Veterinary Parasitology, Islamic Azad University, \\ Iran \\ ${ }^{3}$ Department of Aquatic Animal Health, Faculty of Veterinary \\ Medicine, Iran
}

Correspondence: Abbas Bozorgnia, Assistant Professor, Faculty of Natural Resources Sciences, Qaem Shahr Branch, Islamic Azad University, Iran, Email dr.bozorgnia@gmail.com

Received: May 18, 2018 | Published: May 24, 2018

\section{Introduction}

Lernaea cyprinacea Linnaeus, 1758 (Crustacea: Copepoda) is a parasite of freshwater fishes in various regions of the world and it is often called anchor worm. It is a thermophilic organism and finds excellent conditions for reproduction at temperatures between $23-30^{\circ} \mathrm{C} .{ }^{1,2}$ L.cyprinacea has nine stages throughout its lifetime and goes through many metamorphoses including three free living naupliar stages, five copepodid stages, and one adult stage. ${ }^{3}$ After male and female adults mate on the fish host and then males die, females metamorphose, insert their anterior body into the host tissue whereas the remaining body protrudes in the water. ${ }^{4}$ The invasion of adult female destroys scales, skin, muscles and penetration of the fish body results in deep ulcers, abscesses or fistulas accommodating with serious economic loss and heavy parasitosis could be the cause of mass mortalities and also secondary bacterial or fungal infections. The copepod is also known as a pathogen of cultured and aquarium fishes and typically occurs on the gills. This parasite was described in more than 100 fish species belonging to 25 different families..$^{5}$ Lernaea cyprinacea was accidentally introduced to Iran with exotic cyprinids ${ }^{6}$ and currently it could be found on several species of cultured and wild fish from different families living in aquarium, ponds and natural water bodies throughout the country. Various studies on the occurrence and outbreak of L. cyprinacea have been conducted to date. Barzegar \& Jalali ${ }^{7}$ listed the Crustacean parasites of fresh and brackish (Caspian Sea) water fishes of Iran and reported this parasites on the gills, skin and fins of 14 cultured and wild fish species from 13 genera and four families. Then Pazooki \& Masoumian ${ }^{8}$ made a synopsis of the parasites in Iranian freshwater fishes and added five more species to the list and Raissy et al., ${ }^{9}$ studied the outbreak of L.cyprinacea Linnaeus (Crustacea: Copepoda) in Cyprinid fish from Chaghakhor lagoon. Also the occurrence of L.cyprinacea has been reported on ornamental fished by several researchers. Ebrahimzadeh Mousavi \& Meshgi, et al., ${ }^{10,11}$ reported Lernaea cyprinacea from goldfish, then Adel et al., ${ }^{12}$ recorded L. cyprinacea on Carassius auratus, Poecilia reticulate, Pterophyllum scalare, Symphsodon discus and Poecilia latipinna from local ornamental fish farm in the north of Iran.

Acipenser stellatus Pallas, 1771 is the most euryhaline sturgeon in the Caspian Sea Basin which is reputed to have the tastiest flesh and also the best caviar in Iran. Adults and juveniles occur in the North, Middle and South Caspian at salinity range of $0-14.34 \%{ }^{13}$ but it is now rare in the rivers because of dam construction and irrigation control structures near river mouths which in hibits the spawning in their migration. Kiabi \& Abdoli ${ }^{14}$ consider this species to be vulnerable in the south Caspian Sea basin according to IUCN criteria. The main objective of the current study was to investigate the gill parasites of $A$. stellatus in "Rajaee Aquaculture Centre" in northeast of Caspian Sea Basin, Mazandaran Province.

\section{Material and methods}

A total of 22 individuals of $A$. stellatus, were selected accidentally from "Rajaee Aquaculture Center" situated in Mazandaran Province, Iran and examined for gill parasites during the spring of 2017. After recording biometric characteristics of the fish, the parasites were collected from the gills of fish using dissecting pens, preserved in $70 \%$ ethanol. For light microscopical examination, parasite specimens were cleared, stained and mounted following Kabata et al., ${ }^{15}$ and photographing was made with the aid of a digital microscope camera (Sony, SSC-DC80P). The terminology and measurements were carried out in accordance with the keys were given by Gussev et al., ${ }^{15-17}$

\section{Results}

Six adult female of Lernaea cyprinacea Linnaeus, 1758, with egg sacs were found attached to thefilaments and archs of the examined fish (Figure 1) (Figure 2). The female has a slender and tubular body with $3.9 \pm 0.8 \mathrm{~mm}$ long. The cephalic holdfast was developed well and was comprised a pair of unbranched ventral processes and a pair of larger, slightly dorsal processes. Five (22.7\%) out of 22 specimens of the examined fish, were infected by six adult female of $L$. cyprinacea with egg sacs. 


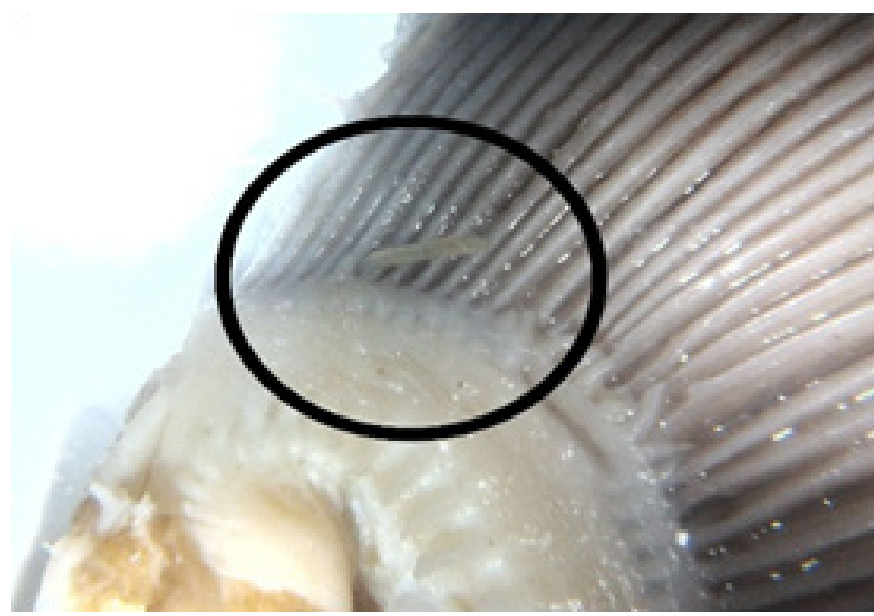

Figure I Female adult of L. cyprinacea on the gill filament of Acipenser stellatus from Rajaee Aquaculture Center, 20 I4. Magnification: I0x.

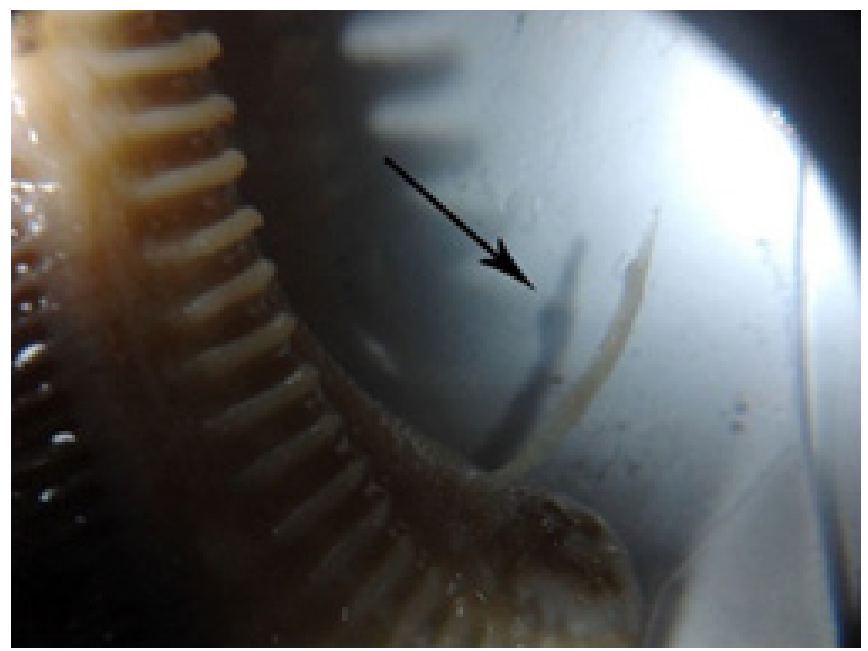

Figure 2 Female adult of L. cyprinacea with egg sacs on the gill arch of Acipenser stellatus from Rajaee Aquaculture Center. 2014. Magnification: I0x.

\section{Discussion}

Considering the commercial importance of the sturgeon, several studies have been carried out on the parasites of different species of the sturgeon particularly A.stellatus in Iran. A total of 15 parasite species have been isolated from different parts of the body of A. stellatus, contains; Diclobothriumarmatum, Nitzschia sturionis, Diplostomum spathaceum, Skrjabinopsolus semiarmatus, Bothrimonus fallax, Eubothrium acipenserinum, Amphilina foliacea, Cucullanus sphaerocephalus, Cyclozon acipenserina, Eustrongilides excisus, Corynosoma capsicum, Corynosoma strumosum, Leptorhynchoides plagicephalus,, Pomphorhynchus leavis, Pseudotracheliastes stellatus $^{17-21}$ and this is the first report of occurrence of adult female of Lernaea cyprinacea on the gills of A. stellatus in all over the world.

In the last decade sturgeons are generally conserved by fish farming and releasing of young and fry, attempting to extend natural populations in Iran. In this regard, Rajaee Aquaculture Center in southeast of Caspian Sea Basin, is produced 2-3 million sturgeon fingerlings including A. stellatus, annually and releases them to
Caspian Sea rivers at the size of 10-15 cm. Rajaee Aquaculture Centre, mainly is a place to produce warm water fishes including common and Chinese carp. So the infestation of A. stellatus by $L$. cyprinacea is probably arrived by infected cyprinoid fishes. In the conditions of farming (high density of fish and appropriate physical and chemical condition such as temperature and salinity) the parasites could established host-parasite systems, completed its life cycle and produced viable eggs.

L. cyprinacea is not host specific and has the widest host range. The parasites with wide host rang are potentially serious danger for fish populations. ${ }^{1,4}$ stage is typically occurs on the gills and adult females usually attach on the body surface and insert their anterior body into superficial layers of the body musculature. They may attach to head, eye, fins, and operculum surface or on buccal cavity of fish specimens and in several cases the parasite specimens penetrated into the body cavity and inserted itself into the liver of fingerlings of fish host. ${ }^{6}$ And this is the first report of occurrence of adult female of L.cyprinacea with egg sacs on the fish gill filaments and archs.

Whitaker \& Schlueter and Barson et al., ${ }^{24,25}$ suggested that differences in susceptibility of fish species to the parasite, could be due to differences in ecological, behavioral and physiological mechanisms and morphological variations. L.cyprinacea is very sensitive to the salinity, the osmolarity of the haemolymph of attached metamorphosed females is similar to that of the host, though attached females can survived in salinity of 15 or $30 \%$ for at least 6 days but failed to produce viable eggs. A. stellatus is an anadromous fish species (spending at least part of its life in salt water and returning to rivers to breed), despite this, the presence of few gill plates under a single large gill operculum which protects the gills cavity, lets copepodid L. cyprinacea to find a suitable place in order to develop to mature. ${ }^{5}$

\section{Conclusion}

In the case of occurrence of infestation in juveniles, after releasing fishes to the rivers, although the parasite may not be able to produce viable eggs but can continue for a long to exist. Definitely as the sturgeon fingerlings are in sensitive ages and endure stressful conditions during their migration to the sea, even mild infection can also lead to reduction of their survival chances and high mortality would be occurred because of respiratory distress through poor gas transfer, slow blood circulation in the gill lamellae and osmoregulation failure. In resistant fish, the parasites may complete its life cycle and produce the new generation that cause infection among the new host species. As A. stellatus is on the list of endangered species and accordance with the commercial value of the fish, preventive measures for pollution control in breeding center is the basics of controlling of the parasites and guarantees the success in the restoration and conservation of the fish stocks in the Caspian Sea.

\section{Acknowledgements}

This research was supported by "Rajaee Aquaculture Centre". We are thankful to Authorities of center who provided expertise that greatly assisted the research.

\section{Conflict of interest}

The author declares that there is no conflict of interest. 


\section{References}

1. Kabata Z. Parasitic Copepoda of British Fishes. Ray Society, London.1979.

2. Lester RJG, Hayward CJ. Phylum Arthropoda. In: Fish Diseases and Disorders. Protozoan and Metazoan Infections. 2nd Edition, PT K Woo, CAB International, Oxfordshire. 2006. p. 466-565.

3. Grabda J. Life cycle and morphogenesis of Lernaeacyprinacea. Acta Parasitologica Polonica.1963;11:169-198.

4. Shariff M, Kabata Z, Sommerville C. Host susceptibility to Lernaea cyprinacea L. and its treatment in a large aquarium system. Journal of Fish Diseases. 1986;9:393-40.

5. Woo PTK. Fish Diseases and Disorders, Volume 1: Protozoan and Metazoan Infections Second Edition. CAB International. UK. 2006.

6. Jalali B. Parasites and parasitic disease of fresh water fishes of Iran. Iranian fisheries Company. 1998.

7. Barzegar M, Jalali B. Crustacean Parasites of Fresh and Brackish (Caspian Sea) Water Fishes of Iran. Journal of Agricultural of Sciences and Technology. 2009;11:161-171.

8. Pazooki J, Masoumian M. Synopsis of the Parasites in Iranian Freshwater Fishes. Iranian Journal of Fisheries Sciences. 2012;11(3):570-589.

9. Raissy M, Sohrabi HR, Rashedi M, et al. Investigation of a parasitic outbreak of Lernaea cyprinacea Linnaeus (Crustacea: Copepoda) in Cyprinid fish from Choghakhor lagoon, Iranian Journal of Fisheries Sciences. 2013;12(3):680-688.

10. Ebrahimzadeh Mousavi H. Diseases of ornamental fish. Scientific Publication. Tehran. 2003.

11. Meshgi B, Eslami A, Yazdani H. Study on the Parasitic Infections of Aquarium Fishes around Tehran. Journal of Veterinary Research. 2006;1(61):1-5

12. Adel M, Ghasempour F, Azizi HR, et al. Survey of parasitic fauna of different ornamental freshwater fish species in Iran. 2015;11(6):75-8.

13. Coad B. Freshwater fishes of Iran. 2017.

14. Kiabi BH. Abdoli AA. preliminary study of inland water fish distribution and abundance in Hormozgan Province (with emphasis on endemic species in rivers). Seventh International Symposium on the Ecology of Fluvial Fishes. 1999;10-13.
15. Kabata Z, Copepoda, Branchiura. In L. Margolis, Z. Kabata, editors. Guide to the Parasites of Fishes of Canada. Part 2, Crustacea. Canadian Special Publication of Fisheries and Aquatic Sciences. 1988. p. 81-96.

16. Gussev AV. Monogenea. In: Bauer ON, editors. Key to parasites of freshwater fishes of USSR. 1st ed. Nauka, Leningrad, USSR.1985.

17. Jalali B. Parasites and parasitic diseases of freshwater fishes of Iran. Iranian Fisheries Research Organization, Tehran.1987; p. 105-112.

18. Hajimoradloo AM. Survey on metazoan parasites infections in Acipenseridae fishes in South-Eastern part of the Caspian Sea. Vet. Ph.D. thesis, Tehran University. 2001.

19. Pyighambari SY. Survey on macroscopic parasites in the gills of Acipenseridae fishes in the Kgyi-Rood Station, B.Sc. thesis, Faculty of Natural Resources, Tehran University. 1991.

20. Mokhayer B. Checklist parasites of Acipenseridae of Iran. Journal Faculty Veterinary Medicine. Tehran University. 1974;(29)1.

21. Sattari M. Survey on metazoan parasites infections in Acipenseridae fishes in South-Western part of the Caspian Sea. Veterinary Ph.D. thesis, Tehran University. 2000.

22. Sattari, M, Mokhayer B, Mihasheminasab M. Survey on intensity parasitic helminthes from Acipenser stellatus fishes of Southeastern part of the Caspian Sea. Journal of Veterinary Faculty. 2002; (57)4.

23. Masoumzadeh M, Sayari M, Shenawar Masouleh AR, et al. Survey on parasitic infection in the digestive tract of Acipenseridae brood stock from Southern part of Caspian Sea. 2nd Symposium on fish health and diseases, Tehran, Iran. 2005.

24. Whitaker JO, Schlueter RA. Occurrence of the crustacean parasite, Lernaea cyprinacea, on fishes from the White River at Petersburg, Indiana. American Midland Naturalist. 1975;93, 446-450.

25. Barson M., Mulonga A., Nhiwatiwa T. Investigation of a parasitic outbreak of Lernaea cyprinacea Linnaeus (Crustacea: Copepoda) in fish from Zimbabwe. African Zoology. 2008;43, 175-183. 